\title{
PENGARUH PRAKTIK KESETARAAN GENDER DAN STATUS GIZI (IMT/U) TERHADAP USIA MENARCHE PADA REMAJA PUTRI DI YAYASAN PERGURUAN KI HAJAR DEWANTARA
}

\author{
Asrika Sari Harahap ${ }^{1}$ \\ ('Departemen Kesehatan Reproduksi Fakultas IImu Kesehatan Masyarakat, \\ Universitas Sumatera Utara) \\ *Correspondence author's email: asrikasariharahap1993@gmail.com
}

\begin{abstract}
Menarche is a menstrual event that occurs for the first time in women. Each adolescent has a variety of ages in reaching sexual maturity. Many factors cause differences in the age of menarche, including nutritional status. This study aims to analyze the effect of gender equality practices and nutritional status (BMI / U) on the age of menarche in young women of Yayasan Perguruan Ki Hajar Dewantara. This type of research is observational analytic with a cross-sectional study design. The data analysis method is path analysis. The population was 784 female students. The sampling technique used simple random sampling, namely 58 students. The results of the study had no direct effect on nutritional status (BMI / U) on the age of menarche. There is a direct influence of intake on nutritional status, namely $\rho$-value = $0.049<0.05$ and gender equality practice on intake, namely the path coefficient value that $\rho$ value $=0.003<0.05$. The conclusion is that there is an indirect effect of gender equality practices on status nutrition and gender equality practice on the age of menarche with beta value on the indirect effect is greater than the beta value on the direct effect. It is recommended to further increase knowledge of gender equality practices, growth and development of young women about the age of menarche and improve diet and see the nutritional status of young women with counseling.
\end{abstract}

Keyoword : Gender Equality Practices; Nutritional Status (IMT/U); Menarche; Teenage Girl

\begin{abstract}
Abstrak
Menarche merupakan peristiwa haid yang terjadi pertama kali pada perempuan. Tiap remaja memiliki variasi usia dalam mencapai maturitas seksualnya. Banyak faktor menyebabkan perbedaan usia menarche, diantaranya status gizi. Penelitian ini bertujuan menganalisis pengaruh praktik kesetaraan gender dan status gizi (IMT/U) terhadap usia menarche remaja putri Yayasan Perguruan Ki Hajar Dewantara. Jenis penelitian ini observasional analitik dengan rancangan penelitian potong lintang (cross-sectional). Metode analisis data yaitu analisis jalur (path analysis). Populasi 784 siswi ,teknik pengambilan sampel menggunakan simple random sampling yaitu 58 siswi. Hasil penelitian secara langsung tidak terdapat pengaruh status gizi (IMT/U) terhadap usia menarche. Secara langsung terdapat pengaruh asupan terhadap status gizi yaitu $\rho$-value $=0,049<0,05$ dan praktik kesetaraan gender terhadap asupan yaitu nilai koefisien jalur bahwa $\rho$-value $=0,003<0,05$. Kesimpulan secara tidak langsung terdapat pengaruh praktik kesetaraan gender terhadap status gizi dan praktik kesetaraan gender terhadap usia menarche dengan nilai beta pada pengaruh tidak langsung lebih besar dibandingkan nilai beta pada pengaruh langsung. Disarankan lebih meningkatkan pengetahuan praktik kesetaraan gender,pertumbuhan dan perkembangan remaja putri tentang usia menarche serta memperbaiki pola makan dan melihat status gizi remaja putri dengan penyuluhan.
\end{abstract}

Kata Kunci : Praktik Kesetaraan Gender; Status Gizi (IMT/U); Usia Menarche; Remaja Putri 


\section{PENDAHULUAN}

Masa remaja atau masa puber adalah suatu tahapan antara masa kanak-kanak dengan masa dewasa. Menurut WHO, disebut remaja adalah penduduk dalam rentang usia 10-19 tahun, menurut Peraturan Menteri Kesehatan Republik Indonesia Nomor 25 tahun 2014, remaja adalah penduduk dalam rentang usia 10-18 tahun dan menurut Badan Kependudukan dan Keluarga Berencana (BKKBN) rentang usia remaja adalah 10-24 tahun dan belum menikah. ${ }^{1}$ Transisi kemasa dewasa memang bervariasi, namun secara umum didefenisikan sebagai waktu dimana individu mulai bertindak terlepas dari orang tua mereka. Pertumbuhan dan perkembangan pada masa remaja sangat pesat, baik fisik maupun psikologisnya. Namun meskipun begitu tak jarang mereka mengalami kegagalan dalam pertumbuhan dan perkembangannya. Banyak faktor yang berpengaruh terhadap kegagalan tersebut seperti genetik, status gizi, sosial, ekonomi, dan lain-lain. ${ }^{2}$

Beberapa faktor tersebut, ada satu faktor yaitu faktor sosial yang seringkali masyarakat lalai dan lupa bahwa hal tersebut juga berpengaruh terhadap kesehatan, namun jarang sekali menjadi perhatian. Permasalahan sosial selalu turut andil dalam setiap permasalahan kesehatan salah satunya adalah ketidaksetaraan gender khususnya kepada wanita, mengingat masalah gender merupakan point kelima dalam 17 goals yang ada dalam SDGs yang berbunyi "menjamin kesetaraan gender serta memberdayakan seluruh wanita dan perempuan". Laporan World Economic Forum (2016) persentase perempuan buta huruf masih banyak sebanyak 4,39 persen, lebih tinggi dari laki-laki 2,29 persen, hal tersebut menunjukkan posisi Indonesia berada pada urutan ke 88 pada indeks kesenjangan gender. ${ }^{3}$ Data Susenas (2015) juga menunjukkan sebanyak 60 persen angkatan kerja di Indonesia berpendidikan rendah di bawah SMA (Sekolah Menengah Atas) dan separuhnya adalah perempuan. Partisipasi perempuan di pasar kerja hanya 49 persen, di bawah rata-rata partisipasi kerja penduduk Indonesia yang mencapai 65,4 persen. ${ }^{4}$

Indonesia merupakan negara ketimuran dengan berbagai adat dan budaya didalamnya. Keseharian,adat dan budaya yang dilakukan masyarakat cenderung berpatokan pada gender dalam setiap pelaksanaannya. Sebagai contoh pandangan bahwa perempuan sebagai ibu rumah tangga dan laki-laki sebagai pencari nafkah membuat derajat wanita seolah-olah lebih rendah dibandingkan dengan laki-laki. Selain itu dengan adanya ketidaksetaraan gender banyak wanita mengalami pelecehan baik itu pelecehan seksual ataupun pelecehan dalam kehidupan sehari-hari, kekerasan, diskriminasi, tidak menjadi diri sendiri, dikekang oleh pasangan dan tidak behagia menjadi perempuan dan tidak hanya itu, dibalik adanya perbedaan peran akibat perbedaan kesetaraan gender juga berpengaruh terhadap kesehatan reproduksi. ${ }^{5}$ 
Masa remaja seringkali perempuan mendominasi terjadinya ketidaksetaraan gender hal tersebut juga tergambar dalam banyaknya terjadi nikah muda, kehamilan remaja, remaja putri kekurangan nutrisi seperti zat besi dan berdampak terjadinya anemia. Ketidaksetaraan terhadap perempuan merupakan pelanggaran terhadap hal asasi manusia. Kekerasan terhadap perempuan harus segera dihapuskan. Maka dari itu diperlukan partisipasi dan kolaborasi dari berbagai elemn masyarakat dan pemerintah dalam memberikan akses dan kesempatan yang setara dalam membangun dan membuat kebijakan untuk menghapuskan kekerasan terhadap perempuan khususnya remaja. ${ }^{6}$ Anemia dapat menimbulkan resiko pada remaja putri baik jangka panjang maupun dalam jangka pendek. Dalam jangka pendek anemia dapat menimbulkan keterlambatan pertumbuhan fisik dan maturitas seksual tertunda. $^{7}$ Dengan tertunda atau terlalu dini maturitas seksual bagi remaja putri akan berdampak pada kesehatannya dimasa mendatang khususnya kesehatan reproduksi. Salah satu bentuk kematangan seksual pada remaja putri ditandai dengan datangnya menarche (menstruasi yang pertama kali datang). Banyak remaja yang mengalami gangguan psikis dengan terlalu dini datangnya usia menarche seperti depresi, rasa takut, bingung, gangguan konsentrasi, mudah tersinggung, gelisah, sukar tidur, sakit kepala, perut kembung dan sebagainya begitu juga sebaliknya. Oleh sebab itu, sangat penting memperhatikan usia menarche pada remaja. ${ }^{8}$

Hasil penelitian Harahap (2011) di wilayah kerja puskesmas Rumbio Jaya Kabupaten Kampar mengenai ketimpangan gender dalam keluarga, ditemukan bahwa ada pengaruh antara distribusi makanan dalam keluarga dan beban ganda ibu hamil dalam keluarga terhadap anemia dalam kehamilan. ${ }^{9}$ Yayasan Perguruan Ki Hajar Dewantara Kotapinang Labuhanbatu Selatan merupakan yayasan terbesar yang ada di Kabupaten Labuhanbatu Selatan yang memiliki jumlah siswa ribuan dan terdiri atas jenjang SMP dan SMK kejuruan dengan 7 jenis kejuruan yang diantaranya akuntansi dan keuangan lembaga, tata kelola perkantoran, teknik komputer dan jaringan, agribisnis tanaman dan hortikultura, asisten keperawatan, tata busanan dan teknik dan bisnis sepeda motor. Yayasan tersebut juga terkenal dengan kegiatan ekskul yang sangat aktif yang didominasi dengan kegiatan olahraga.

Hasil observasi pada siswa/i di Yayasan Perguruan Ki Hajar Dewantara yang memiliki dua sekolah yaitu SMP (sekolah menengah pertama) dan SMK (sekolah menengah kejuruan) terlihat bahwa banyak siswa/i dengan postur tubuh kurus bahkan sangat kurus serta di antaranya juga memiliki tinggi badan kategori pendek. Kedua hal tersebut termasuk dalam indikator status gizi yang tidak baik. Peneliti juga melakukan metode wawancara kepada 20 siswi yang memiliki postur tubuh kurus mengatakan bahwa melakukan banyak kegiatan di sekolah maupun di rumah (membantu orangtua), malas makan, tidak selera 
makan, tidak sempat sarapan, tidak tahu (genetik) dan lain sebagainya. Sebanyak 20 siswi yang diwawancarai oleh peneliti ternyata ada 12 diantaranya mengatakan banyak pekerjaan di rumah membantu orangtua sehingga kelelahan dan lupa makan dan 10 diantaranya juga belum mengalami menarche. Sedangkan, pada siswa yang diwawancarai tentang postur tubuh kurus mengatakan sibuk bermain sehingga lupa makan, malas makan dan tidak tahu dan lain sebagainya. Yayasan Perguruan Ki Hajar Dewantara merupakan sekolah dengan fasilitas terlengkap mulai dari sarana maupun prasarananya. Siswa dan siswi yang bersekolah di yayasan tersebut rata-rata memiliki status ekonomi menengah keatas. Hal tersebut ditandai dengan hampir seluruh siswa dan siswi memiliki transportasi pribadi (motor/mobil) dan biaya sekolah per bulannya sangat mahal yaitu seratus lima puluh ribu.

Peneliti melakukan survei awal dengan metode wawancara dan melakukan pengukuran tinggi badan serta berat badan untuk mengkaji status gizi remaja putri. Yayasan Perguruan Ki Hajar Dewantara Kotapinang terdiri dari 1555 siswa dan siswi yaitu SMP sejumlah 196 orang yaitu 95 siswi dan 101 siswa dan SMK berjumlah 1359 yang terdiri 689 siswi dan 670 siswa. Jumlah total siswi sebanyak 784 siswi. Hasil penelitian awal yang didapatkan oleh peneliti diantaranya terdapat 410 siswi yang mengalami indeks massa tubuh kategori kurus, normal sebanyak 267 dan gemuk sebanyak 107 sedangkan yang mengalami keterlambatan usia menarche sebanyak 209, normal sebanyak 201 siswi dan cepat sebanyak 374 siswi. Adapun tujuan penelitian ini adalah untuk mengetahui pengaruh secara langsung maupun tidak langsung antara praktik kesetaraan gender dan status gizi (imt/u) terhadap usia menarche pada remaja putri.

\section{METODE PENELITIAN}

Jenis penelitian yang digunakan dalam penelitian ini adalah observasional analitik dengan rancangan penelitian potong lintang (cross sectional). Penelitian ini, mengetahui pengaruh antara variabel yang memengaruhi (exogenous variable) dengan variabel yang dipengaruhi (endogenous variable) melalui variabel intervening (intervening variable). Penelitian ini dilakukan di Yayasan Perguruan Ki Hajar Dewantara Kotapinang Labuhanbatu Selatan pada bulan Desember sampai dengan Juli 2018. Populasi penelitian ini adalah seluruh siswi SMP-SMK Ki Hajar Dewantara Kotapinang mulai dari kelas VII sampai dengan kelas XII yang sudah maupun belum mengalami menarche yaitu 784 siswi sedangkan jumlah sampel yaitu sebanyak 58 siswi. Tehnik pengambilan sampel dalam penelitian ini menggunakan simple random sampling. Dari hasil perhitungan sampel yang dihitung jumlah responden tiap kelasnya, akan diambil secara acak dengan cara undian. Pengumpulan data dilakukan menggunakan angket dengan cara pengisian lembar kuesioner berisi pertanyaan yang harus dijawab oleh responden dan melakukan pengukuran tinggi badan 
serta berat badan dalam menentukan status gizi responden.

Adapun definisi operasional pada penelitian ini yaitu yang menjadi variabel eksogen adalah praktik kesetaraan gender yaitu perlakuan orangtua terhadap anak laki-laki dan anak perempuan, variabel interveningnya adalah asupan (cara pemberian atau pembagian makanan oleh orang tua terhadap anak laki-laki dan anak perempuan) dan status gizi (imt/u) (ukuran berat badan $(\mathrm{kg})$ dibandingkan dengan tinggi badan $\left(\mathrm{m}^{2}\right)$ berdasarkan umur sehingga didapatkan hasil status gizi dengan indeks antropometri). Sedangkan variabel endogen yaitu usia menarche yang artinya usia dimana remaja putri pertama kali mendapatkan haid pertama. Metode analisis data yang digunakan dalam penelitian ini adalah Analisis Jalur (Path Analysis). Model path analysis digunakan untuk menganalisis pola pengaruh antar variabel dengan tujuan untuk mengetahui pengaruh langsung dan tidak langsung exogenous variable dengan endogenous variablemelalui intervening variable. Untuk menentukan pengaruh langsung atau tidak langsung dengan melihat besar nilai signifikasi dan nilai beta atau nilai koefisien regresi dengan menggunakan SPSS. Selama penelitian berlangsung adapun yang menjadi kendala dalam penelitian ini adalah cara pengisian kuesioner oleh responden yang hanya mengandalkan ingatan responden.

\section{HASIL PENELITIAN}

Tabel 1. Karakteristik Responden Berdasarkan Umur, Kelas, Suku, Jumlah Saudara Laki-laki dan Anak ke Berapa

\begin{tabular}{|c|c|c|c|}
\hline Variabel & & $\mathrm{F}$ & Persentase (\%) \\
\hline \multirow[t]{3}{*}{ Umur } & $13-14$ & 5 & 8,6 \\
\hline & $15-16$ & 32 & 55,2 \\
\hline & $17-18$ & 21 & 36,2 \\
\hline \multirow[t]{6}{*}{ Kelas } & Kelas VII & 3 & 5,2 \\
\hline & Kelas VIII & 2 & 3,4 \\
\hline & Kelas IX & 2 & 3,4 \\
\hline & Kelas X & 22 & 37,9 \\
\hline & Kelas XI & 15 & 25,9 \\
\hline & Kelas XII KK & 14 & 24,1 \\
\hline \multirow[t]{4}{*}{ Suku } & Batak & 40 & 68,9 \\
\hline & Jawa & 16 & 27,6 \\
\hline & Melayu & 1 & 1,7 \\
\hline & Banjar & 1 & 1,7 \\
\hline \multirow[t]{4}{*}{ Jumlah Saudara Laki-laki } & 1 & 42 & 72,4 \\
\hline & 2 & 10 & 17,2 \\
\hline & 3 & 4 & 6,9 \\
\hline & 4 & 2 & 3,4 \\
\hline \multirow[t]{3}{*}{ Anak Ke Berapa } & 2 & 31 & 53,4 \\
\hline & 3 & 19 & 32,8 \\
\hline & 4 & 8 & 13,8 \\
\hline
\end{tabular}


Tabel 1. Menjelaskan bahwa hasil penelitian yang dilakukan terhadap 58 siswa/siswi di Yayasan Perguruan Ki Hajar Dewantara Kotapinang Kabupaten Labuhanbatu Selatan melalui wawancara dapat dilihat bahwa sebagian besar responden berumur 15-16 tahun yaitu sebesar $55,2 \%$. Berdasarkan kelas responden bahwa sebagian besar responden adalah kelas $\mathrm{X}$ yaitu sebesar $37,9 \%$. Karakteristik responden berdasarkan suku pada siswi menyatakan bahwa hampir seluruh siswi bersuku batak yaitu 68,9\% sedangkan siswi dengan suku jawa sebanyak $27,6 \%$ dan disusul dengan melayu dan banjar masing-masing $1,7 \%$. Adapun jumlah saudara laki-laki yang dimiliki oleh siswi didominasi dengan jumlah saudara laki-laki sebanyak 1 orang dengan nilai persentase $74,1 \%$ kemudian siswi yang memiliki jumlah saudara laki-laki sebanyak 2 orang nilai persentase 15,5\% sedangkan jumlah saudara laki-laki sebanyak 3 orang nilai persentase $6,9 \%$ dan paling sedikit siswi memiliki saudara laki-laki sebanyak 4 orang dengan nilai persentase $3,5 \%$. Karakteristik anak ke berapa menjelaskan bahwa banyaknya responden berada pada urutan kedua didalam keluarga sebagai seorang anak di dalam keluarganya yaitu sebanyak $53,4 \%$ dan selanjutnya disusul dengan anak ketiga yaitu sebesar $32,8 \%$ dan anak keempat yaitu $13,8 \%$.

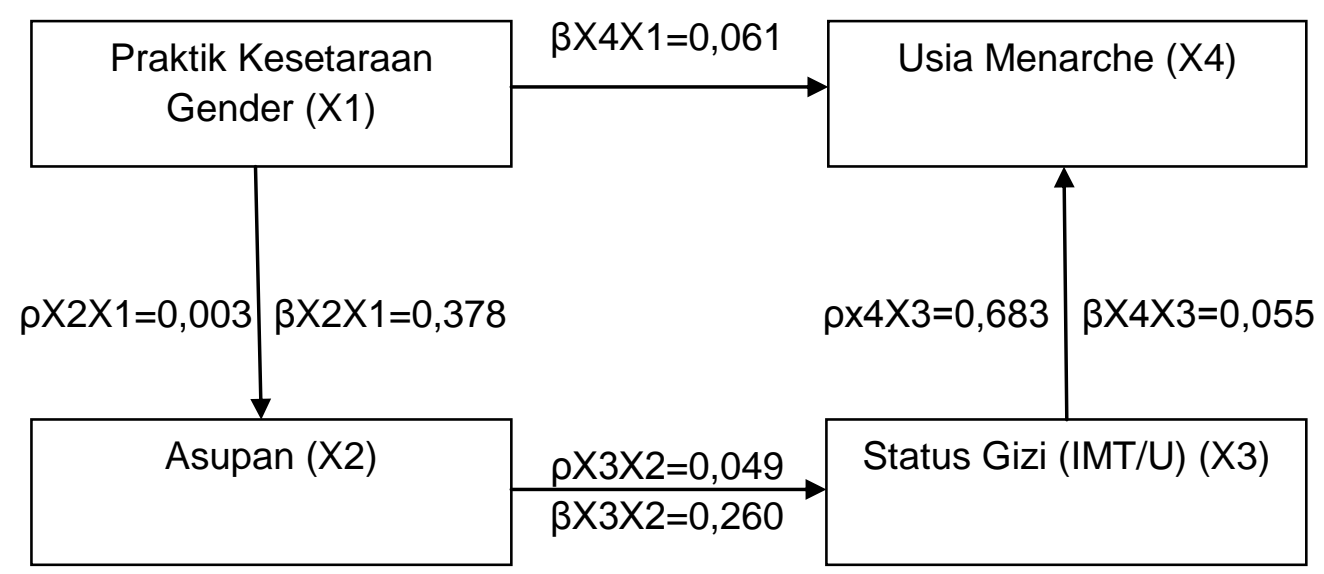

\section{Gambar 1. Pengaruh Praktik Kesetaraan Gender dan Status Gizi (IMT/U) terhadap Usia Menarche}

Gambar 1. menjelaskan bahwa nilai koefisien jalur secara langsung antara praktik kesetaraan gender (X1) terhadap asupan (X2) adalah diperoleh nilai yaitu $\rho$ X2X1=0,003 dan $\beta X 2 X 1=0,378$, asupan (X2) terhadap status gizi $(X 3)$ didapatkan hasil yaitu nilai $\rho \times 3 \times 2=0,049$ dan $\beta \times 3 X 2=0,260$ dan nilai status gizi (X3) terhadap usia menarche (X4) yaitu diperoleh nilai $\rho X 4 X 3=0,683$ dan $\beta X 4 X 3=-0,055$ dan nilai koefisien jalur secara langsung antara praktik kesetaraan gender dan usia menarche didapatkan hasil yaitu $\beta X 4 X 1=-0,061$, dengan penjelasan nilai-nilai tersebut makan dapat disimpulkan bahwa secara langsung terdapat pengaruh X1 (praktik kesetaraan gender) terhadap X2 (asupan), hal itu ditandai Penerbit: Poltekkes Kemenkes Padang, http://jurnal.poltekkespadang.ac.id/ojs/index.php/jsm 
dengan hasil perhitungan $\rho \mathrm{X} 2 \mathrm{X} 1=0,003<0,05$ kemudian antara variabel X2 (asupan) dan X3 (status gizi) didapatkan hasil bahwa terdapat pengaruh langsung yaitu dapat dilihat pada nilai $\rho X 3 X 2=0,049<0,05$ dan hasil perhitungan X3 (status gizi) terhadap X4 (usia menarche) diperoleh hasil $\rho \times 4 X 3=0,683>0,05$ yang berarti didapatkan kesimpulannya adalah bahwa tidak terdapat pengaruh langsung status gizi (IMT/U) terhadap usia menarche.

Pengaruh tidak langsung praktik kesetaraan gender terhadap status gizi(IMT/U) dimulai dengan melakukan perhitungan pengaruh langsung yang diberikan X1 (praktik kesetaraan gender) terhadap X3 (status gizi) didapatkan nilai $\beta=0,093$ sedangkan pengaruh tidak langsung X1 (praktik kesetaraan gender) melalui X2 (asupan) terhadap X3 (status gizi) adalah perkalian antara nilai $\beta \mathrm{X} 1$ terhadap $\beta \mathrm{X} 2$ dengan nilai $\beta \mathrm{X} 2$ terhadap $\beta \mathrm{X} 3$ yaitu $0,378 \times 0,260=0,098$, maka pengaruh total yang diberikan $X 1$ (praktik kesetaraan gender) terhadap X3 (status gizi) adalah pengaruh langsung ditambah dengan pengaruh tidak langsung yaitu $0,093+0,098=0,191$. Berdasarkan hasil perhitungan diperoleh nilai pengaruh langsung sebesar $\beta=0,093$ dan pengaruh tidak langsung $\beta=0,098$ yang berarti bahwa nilai pengaruh tidak langsung lebih besar dibandingkan dengan nilai pengaruh langsung, hasil ini menunjukkan bahwa secara tidak langsung X1 (praktik kesetaraan gender) melalui X2 (asupan) mempunyai pengaruh signifikan terhadap X3(status gizi).

Pengaruh praktik kesetaraan gender terhadap usia menarche didapatkan hasil perhitungan yaitu pengaruh langsung yang diberikan $X_{1}$ (praktik kesetaraan gender) terhadap X4 (usia menarche) didapatkan nilai $\beta=-0,061$ sedangkan pengaruh tidak langsung X1 (praktik kesetaraan gender) melalui X2 (asupan) dan X3 (status gizi) terhadap X4 (usia menarche) adalah perkalian antara nilai $\beta$ X1 terhadap $\beta$ X2 dengan nilai $\beta$ X2 terhadap $\beta$ X3 dan $\beta$ X3 terhadap $\beta$ X4 yaitu $0,378 \times 0,260 \times-0,055=-0,0054$, maka pengaruh total yang diberikan X1 (praktik kesetaraan gender) terhadap X4 (usia menarche) adalah pengaruh langsung ditambah dengan pengaruh tidak langsung yaitu $-0,061+(-0,0054)=-0,0664$. Berdasarkan hasil perhitungan diperoleh nilai pengaruh langsung sebesar $\beta=-0,061$ dan pengaruh tidak langsung $\beta=-0,0054$ yang berarti bahwa nilai pengaruh tidak langsung lebih besar dibandingkan dengan nilai pengaruh langsung, hasil ini menunjukkan bahwa secara tidak langsung X1 (praktik kesetaraan gender) melalui X2 (asupan) dan X3 (status gizi) mempunyai pengaruh signifikan terhadap X4 (usia menarche).

\section{PEMBAHASAN}

Praktik kesetaraan gender antara laki-laki dan perempuan masih seringkali terjadi di masyarakat. Banyak orang tua yang masih memiliki pemikiran bahwa anak laki-laki lebih diistimewakan karena akan menjadi pemimpin dikeluarganya sedangkan anak perempuan tidak termasuk dalam pembagian makanan atau asupan. Hasil penelitian pada siswi di Penerbit: Poltekkes Kemenkes Padang, http://jurnal.poltekkespadang.ac.id/ojs/index.php/jsm 
Yayasan Perguruan Ki Hajar Dewantara Kotapinang, praktik kesetaraan gender memiliki pengaruh langsung terhadap asupan, praktik kesetaraan gender dalam penelitian ini dapat dilihat dari asupan yang diperoleh. Penelitian ini sejalan dengan Harahap (2011) tentang pengaruh ketimpangan gender dalam keluarga dan karakteristik ibu terhadap anemia dalam kehamilan di Wilayah Kerja Puskesmas Rumbio Jaya Kabupaten Kampar dengan variabel paling besar pengaruhnya terhadap anemia dalam kehamilan adalah distribusi makanan yaitu nilai $\mathrm{OR}=4,338$ yang artinya resiko terjadinya anemia dalam kehamilan pada ibu yang mengalami ketimpangan gender 4,3 kali lebih besar dibandingkan ibu yang tidak mengalami ketimpangan gender.(9) Penelitian Linda (2013) juga menunjukkan ada pengaruh perspektif gender terhadap kejadian anemia pada ibu hamil $(p=0,027)$ dengan nilai koefisien regresi=2,363 sehingga dapat dinyatakan semakin baik partisipasi suami dalam perawatan kehamilan maka semakin rendah angka kejadian anemia. ${ }^{10}$

Praktik kesetaraan gender merupakan pokok masalah dimasyarakat menurut UNICEF (2013) selain itu juga merupakan salah satu point yang menjadi perhatian dalam SDGs namun hasil dari penelitian memberikan kesimpulan bahwa praktik kesetaraan gender yang terjadi di Yayasan Perguruan Ki Hajar Dewantara termasuk dalam kategori kurang baik karena masih adanya perspektif yang menganggap bahwa anak laki-laki menjadi seorang yang harus diutamakan dalam keluarga. Hasil penelitian juga menunjukkan bahwa dengan praktik kesetaraan gender yang setara maka akan mempengaruhi asupan antara anak lakilaki dan perempuan tidak ada perbedaan pula begitu juga sebaliknya jika praktik kesetaraan gender tidak setara maka asupan juga yang diberikan orang tua antara anak laki-laki dan perempuan juga tidak setara. ${ }^{11}$

Asupan memiliki pengaruh secara langsung terhadap status gizi (IMT/U), asupan dapat diketahui dengan melihat cara pemberian atau pembagian makanan oleh orangtua terhadap anak laki-laki dan perempuan. Asupan dapat dikatakan setara jika pemberian atau pembagian makanan antara anak laki-laki dan perempuan sama atau tidak ada perbedaan. Menurut UNICEF (2013) normal tidaknya status gizi (IMT/U) merupakan salah satu indikator yang dipengaruhi oleh asupan, ada hal lain yang menjadi penyebab langsung normal tidaknya status gizi (IMT/U) seperti penyakit infeksi. ${ }^{11}$ Penelitian Khalimatus (2015) menyatakan terdapat hubungan yang signifikan antara pola makan dan status gizi anak usia prasekolah yang ditandai dengan nilai $p(0,038)>0,05 .{ }^{12}$ Penelitian Cahyaputra (2016) juga menunjukkan bahwa ada hubungan status gizi dengan pola makan pagi ditandai dengan nilai $r$ hitung lebih besar lebih besar dibanding $r$ tabel yaitu $0,570>0,231 .^{13}$

Permasalahan gizi juga dipengaruhi oleh faktor langsung dan tidak langsung, pengaruh tersebut diperoleh dari pokok permasalahan dan akar masalah yang tidak hanya bersumber dari sektor kesehatan. Terdapat berbagai sektor yang memengaruhi status gizi, diantaranya Penerbit: Poltekkes Kemenkes Padang, http://jurnal.poltekkespadang.ac.id/ojs/index.php/jsm 
pertanian, keamanan pangan, pendidikan, fasilitas umum terkait sanitasi dan pembangunan, perindustrian dan perdagangan, sosial, ketenagakerjaan, ekonomi,komunikasi dan informasi serta kepemimpinan dan kebijakan lokal nasional. Untuk mencapai perbaikan gizi diperlukan adanya peran serta dari seluruh sektor terkait.

Status gizi (IMT/U) tidak memiliki pengaruh langsung terhadap usia menarche, dapat dikatakan bahwa normal tidaknya status gizi (IMT/U) tidak berpengaruh terhadap usia menarche remaja putri. Penelitian Antono (2015) tentang hubungan antara status gizi (IMT/U) dengan usia menarche pada remaja putri usia 13-14 tahun di SMPN 1 Pace Kecamatan Pace Kabupaten Nganjuk menyatakan bahwa tidak ada hubungan antara status gizi (IMT/U) dengan usia menarche ditandai dengan uji korelasi spearman rank didapatkan hasil t hitung $<$ t tabel. ${ }^{14}$ Penelitian Ayuningtyas (2012) juga menyatakan tidak ada hubungan antara status gizi (IMT/U) dengan usia menarche dikarenakan hasil pengolahan data didaptkan bahwa $\mathrm{p}$ value $(0,062)>0,05$ yang berarti $\mathrm{H} 0$ gagal ditolak. ${ }^{15}$

Pertumbuhan dan perkembangan remaja putri salah satunya ditandai dengan terjadinya menarche. Menarche merupakan bentuk kematangan seksual pada remaja putri namun demikian usia menarche remaja putri yang satu dengan yang lainnya dapar bervariasi. Banyak faktor yang menyebabkan terjadinya variasi usia menarche. Menurut Fikawati (2017) terdapat beberapa faktor yang mempengaruhinya seperti keadaan gizi, kesehatan umum, faktor keturunan dan tingkat stres. ${ }^{16}$ Status gizi (IMT/U) merupakan salah satu diantaranya namun pada remaja putri di Yayasan Perguruan Ki Hajar Dewantara tidak berpengaruh signifikan terhadap usia menarche.

Variasi usia menarche lebih dominan terjadi bukan hanya keadaan gizi namun kegiatan pada masa remaja yang sangat banyak menyebabkan tingkat stres yang lebih tinggi dimana pada masa itu juga masa yang sangat rentan akan pengaruh teman baik yang baik maupun tidak baik sehingga tekanan pada masa itu menyebabkan tingginya tingkat stres remaja. Hasil penelitian menunjukkan bahwa praktik kesetaraan gender memiliki pengaruh secara tidak langsung terhadap status gizi (IMT/U), artinya baik tidaknya praktek kesetaraan gender dapat berpengaruh secara tidak langsung terhadap status gizi (IMT/U). Besarnya pengaruh tidak langsung praktik kesetaraan gender terhadap status gizi (IMT/U) adalah nilai pengaruh langsung sebesar $-0,079$ dan pengaruh tidak langsung $-0,0514$ yang berarti bahwa nilai pengaruh tidak langsung lebih besar dibandingkan dengan nilai pengaruh langsung, hasil ini menunjukkan bahwa secara tidak langsung praktik kesetaraan gender melalui pola makan mempunyai pengaruh signifikan terhadap status gizi (IMT/U). Sejalalan dengan penelitian Hardisman (2011) dengan menggunakan Harvard Framework serta Moser and Liverpool Guideline yang menyatakan bahwa kasus malnutrisi anak di Indonesia sangat dipengaruhi oleh kondisi sosial, budaya, dan ekonomi termasuk tingkat pendidikan dan kesetaraan Penerbit: Poltekkes Kemenkes Padang, http://jurnal.poltekkespadang.ac.id/ojs/index.php/jsm 
gender. Dalam perspektif gender, malnutrisi anak merupakan akibat dari kurangnya hak kepemilikan sumber daya bagi perempuan dalam keluarga dan masyarakat. Beban kerja berat perempuan dalam keluarga yang mempengaruhi kondisi kesehatan juga akhirnya berdampak pada kondisi gizi anak. ${ }^{17}$

Praktik kesetaraan gender melalui pola makan memberikan pengaruh yang signifikan terhadap status gizi remaja putri dikarenakan dengan praktik kesetaraan gender yang baik atau setara maka akan mempengaruhi pola makan remaja dengan baik pula sehingga menyebabkan status gizi (IMT/U) remaja putri juga baik. Penerapan praktik kesetaraan gender yang seimbang menjadikan remaja putri dapat terbantu dalam meningkatkan kesehatannya. Pengaruh tidak langsung praktik kesetaraan gender terhadap usia menarche dalam penelitian didapatkan hasil bahwa terdapat pengaruh secara tidak langsung antara kedua variabel tersebut yang berarti baik tidaknya praktik kesetaraan gender dapat berpengaruh secara tidak langsung terhada usia menarche. Besarnya pengaruh tidak langsung praktik kesetaraan gender terhadap usia menarche adalah nilai pengaruh langsung sebesar -0,061 dan pengaruh tidak langsung 0,0035 yang berarti bahwa nilai pengaruh tidak langsung lebih besar dibandingkan dengan nilai pengaruh langsung, hasil ini menunjukkan bahwa secara tidak langsung praktik kesetaraan gender melalui pola makan dan berdampak pada status gizi (IMT/U) mempunyai pengaruh signifikan terhadap usia menarche.

Praktik kesetaraan gender yang setara akan berpengaruh terhadap pola makan remaja putri yang baik sehingga berdampak pada keadaan status gizi (IMT/U) yang baik pula sedangkan dengan keadaan status gizi yang baik dapat mempengaruhi normal tidaknya usia menarche pada remaja putri. Adapun manfaat dengan adanya praktik kesetaraan gender terhadap usia menarche adalah akan menjadikan khususnya orang tua tidak lagi membeda-bedakan antara hak serta kewajiban antara anak laki-laki dan perempuan sehingga dalam hal ini yang sangat berpengaruh adalah makanan atau asupan dan beban kerja sehingga tidak mengganggu perkembangan sistem reproduksi seperti terjadinya ketidaknormalan usia menarche.

Adapun hal yang dapat terjadi apabila praktik kesetaraan gender tidak berjalan dengan baik maka akan dapat menjadikan proses perkembangan dan pertumbuhan khususnya remaja putri akan terhambat sehingga akan berefek pada terganggunya sistem reproduksi seperti selain usia menarche yang lambat atau cepat juga membuat gangguan pada hai seperti hipermenorhae, hipomenerhae dan lain sebagainya. 


\section{SIMPULAN DAN SARAN}

Hasil penelitian menyimpulkan bahwa secara tidak langsung terdapat pengaruh praktik kesetaraan gender terhadap status gizi dan praktik kesetaraan gender terhadap usia menarche dengan nilai beta pada pengaruh tidak langsung lebih besar dibandingkan nilai beta pada pengaruh langsung. Disarankan lebih meningkatkan pengetahuan praktik kesetaraan gender,pertumbuhan dan perkembangan remaja putri tentang usia menarche serta memperbaiki pola makan dan melihat status gizi remaja putri dengan penyuluhan.

\section{UCAPAN TERIMAKASIH}

Penulis menyampaikan ucapan terimakasih kepada Ketua Yayasan Ki Hajar Dewantara Kotapinang Labuhanbatu Selatan yang telah membanntu terlaksananya penelitian ini. Ucapan terimakasih juga disampaikan kepada para guru dan staf tata usaha yang telah membantu proses pengumpulan data di kelas maupun lapangan sekolah.

\section{DAFTAR PUSTAKA}

1. Infodatin. Situasi Kesehatan Reproduksi Remaja. 2012;

2. Proverawati. Menarch (Menstruasi Pertama Penuh Makna). In: Yogyakarta: Nuha Medika. 2011.

3. World Economic Forum. The Global Gender Gap Report. 2017;Diakses 27 mei 2018; https://www.google.com.

4. Badan Pusat Statistik. Survei Sosial Ekonomi Nasional (SUSENAS) Tahun 2010. In: Jakarta : Badan Penelitian dan Pengembangan kesehatan.

5. Wayanarmini. No Title. 2015;https://www.google.com/amp/s/midwifesience.wordpre.

6. Fakih M. Analisis Gender dan Transformasi Sosial. In: Yogyakarta: INSISTPress. 2012.

7. Helena. Gambaran Pengetahuan Gizi Ibu Hamil Trimester Pertama dan Pola Makan dalam Pemenuhan Gizi. 2013;www.repository.usu.ac.id. Diakses tanggal 05 Oktob.

8. Irianto K. Gizi Seimbang dalam Kesehatan Reproduksi. In: Bandung: Alfabeta. 2014.

9. Harahap, J R. Pengaruh Ketimpangan Gender dalam Keluarga dan Karakteristik Ibu Terhadap Anemia dalam Kehamilan di Wilayah Kerja Puskesmas Rumbio Jaya Kabupaten Kampar. Tesis. 2011;

10. Linda I. Perspektif Jender Terhadap Kejadian Anemia Pada Ibu Hamil di Wilayah Kerja Puskesmas Pantai Cermin Kabupaten Langkat. J Precure. 2013;Volume 1 A.

11. UNICEF. Nutritional Status. In: Jakarta. 2013.

12. Khalimatus L. Hubungan Pola Makan dengan Status Gizi Ana Pra Sekolah di Paud Tunas Mulia Claket Kecamatan Pacet Mojokerto. LTA. 2015;

Penerbit: Poltekkes Kemenkes Padang, http://jurnal.poltekkespadang.ac.id/ojs/index.php/jsm 
13. Cahyaputra E. Hubungan Pola Makan, Status Gizi dan Tingkat Kebugaran Jasmani Siswa Kelas Atas SD Rejosari 3 Semin Gunungkidul. Skripsi. 2016;

14. Antono S. Hubungan antara Status Gizi dengan Usia Menarche pada Remaja Putri Usia 13-14 Tahun di SMPN 1 Pace Kecamatan Pace Kabupaten Nganjuk. 2015;

15. Ayuningtyas S. Hubungan Status Gizi dengan Usia Menarche pada Siswi SMPN 1 Jember. Skripsi. 2012;

16. Fikawati S. Gizi Anak dan Remaja. In: Depok: Raja Grafindo Persada. 2017.

17. Hardisman. Peranan Pemberdayaan Perempuan dan Analisis Gender pada Penentuan Kebijakan Pengentasan Malnutrisi Anak di Indonesia. Artikel Telaahan. 2011; 